\title{
Public Infrastructure and Economic Growth in Pakistan: A Dynamic CGE-Microsimulation Analysis
}

\author{
Vaqar Ahmed, Ahsan Abbas, and Saira Ahmed
}

\section{Introduction and Background}

The role of infrastructure in economic growth and welfare has been studied extensively across the literature over the past three decades. Post World War II reconstruction presented a model where governments invested in economies in order to create an enabling environment for the private sector. This led to infrastructure being viewed as something along the lines of a public good, and in many countries its provision became the sole responsibility of the state.

Later, many experts realized that infrastructure needs to be divided into public works (mainly construction of infrastructure) and public service delivery (provision of utilities such as electricity and water). ${ }^{1}$ While the former remains a public sector domain in developing countries, public service delivery has seen the involvement of the private sector through unbundling of supply chains.

More recently in the wake of commodity price hikes and the global financial crisis, developing countries have found it hard to sustain investment in infrastructure (Planning Commission 2011). This has led to the closure of mega projects, particularly in the energy and water sectors, in association with escalating costs, time overruns, etc. Governments are increasingly turning to alternative modes of financing, including private sector participation such as public private partnership models and build-operate-own models. However, even these modes of financing have proven challenging as most developing countries have yet to come up with a legal and regulatory framework for such transactions. Until such a framework

\footnotetext{
${ }^{1}$ See World Bank (1994) for more on this.

V. Ahmed $(\varangle) \cdot$ A. Abbas

Sustainable Development Policy Institute, Islamabad, Pakistan

e-mail: vaqar@sdpi.org; ahsan_abbas32@yahoo.com

S. Ahmed

IMT Institute of Advanced Studies, Italy

e-mail: saira.ahmed2@gmail.com
} 
exists, infrastructure financing will continue through foreign aid, collecting taxes and imposing development and user charges (Lin 2011).

As a developing country, Pakistan is also faced with infrastructure issues which can be classified into broad headings of quantity, efficiency and financing. Interand intra-regional inequalities exist in access to even basic infrastructure. This situation has forced people to migrate to cities in search of increased opportunities. Today, Pakistan has the fastest urbanization rate in all of South Asia. This has put pressures on already stressed urban infrastructure.

In view of the above mentioned, this paper investigates two modes of financing public infrastructure: international borrowing and production taxes. The next section provides a brief literature review on the subject and is followed by discussion of the current state of infrastructure in Pakistan. Section "Data and Parameterization" discusses the data and parameterization. Section "Results" explains our results and the section "Conclusion" concludes with policy recommendations.

\section{Infrastructure and Economic Growth}

We divide the literature into two quantitative streams, primarily for methodological ease. The first stream uses econometric tools to study the impact of infrastructure on growth and the second uses a computable general equilibrium model.

\section{Global Evidence}

The World Bank (1994) provides important insight into infrastructure dynamics from an availability, efficiency and financing point of view, but it defined infrastructure from the narrow perspective of public services comprised of electricity, energy and water, as well as public works, primarily roads and other transportation infrastructure such as rail, port and airports. The seminal work by Aschauer (1989) shows significant impact of public capital on growth has results which are contrary to those of Holtz-Eakin (1994). Aschauer (1998) later suggested, for the case of Mexico, that large public investments are an insufficient condition for growth, and must be complemented by policies regarding the financing and use of infrastructure. Most of the earlier literature is silent on the impact of infrastructure on poverty and inequality.

Looking at infrastructure through disaggregated spending is also important. Public expenditures on connectivity and ICT play an important role in facilitating growth processes. Connectivity between people and places has been shown to overcome urban-rural, gender and human capital disparities. Lall (2006), taking a pooled dataset of Indian states, shows that spending on transport and communications infrastructure are significant determinants of regional growth. There are positive externalities from investments by local and neighbouring states. Devarajan 
et al. (1996) had previously found a negative and significant relationship between economic growth and transport and communications expenditures-to-total expenditures ratio in their sample of countries, and attributed this to the possibility that overinvestment in transport and communications makes such expenditures relatively unproductive. Canning and Pedroni (2008) analyze a panel of countries from 1950 to 1992 and show that infrastructure does not tend to cause growth in the longer run, although there is variation across countries. Infrastructure is undersupplied in some countries and oversupplied in others.

In the same cross-country regression tradition, Sanchez-Robles (1998) used the quantity of public infrastructure stock (measured through indices) rather than public infrastructure expenditures and found a positive and significant relationship. The author stressed the need to ensure the efficiency of public investment for optimal absorption. Accountability and civil service reforms need to be established as part of robust monitoring and evaluation for projects funded through either taxation or foreign aid (Planning Commission 2011).

Straub et al. (2008) show for East Asia that the failure to find a significant link between infrastructure, productivity and growth may arise because investments in infrastructure were made to relieve constraints and bottlenecks (where they existed) rather than to directly encourage growth.

In time-series studies, Nketiah-Amponsah (2009) show for Ghana that aggregate government expenditures over 1970-2004 negatively impacted economic growth. More specifically, disaggregated (short run) health and infrastructure expenditures positively affected growth and education expenditures negatively impacted growth. The political economy variables such as governance and political instability were significant in explaining growth. Sahoo and Dash (2009) also show for India that the stock of infrastructure positively contributes to growth with unidirectional causality from infrastructure development to output growth.

Some existing CGE studies investigate the economy-wide impact of public infrastructure. Rioja (2001), in general equilibrium studies on Brazil, Mexico and Peru, show that these countries underinvested in infrastructure during 1970s and 1980s. The simulations suggest that infrastructure can positively impact output, private investment and welfare.

Estache et al. (2009) show for Mali that foreign aid-funded infrastructure does produce Dutch Disease effects, but that the negative impacts differ by the type of investment, while economic growth attenuates these negative effects.

Dissou and Didic (2011) found for Benin that the crowding out effects of public infrastructure is sensitive to the mode of financing chosen by the government. Overall, their findings suggest that public investment in infrastructure can support private investment and sustain capital accumulation. The positive impact of public investment on private investment can be explained through the infrastructure financing channels such as public private partnerships and sub-contracting which in turn tend to crowd-in private investment. 


\section{Pakistan's Context}

In the case of Pakistan there are several studies showing a negative or insignificant impact of aggregate public investments on growth. These include Ghani and Din (2006), Rehman et al. (2010) and the Planning Commission (2011). Sadly, not enough work has been done to quantify the economy-wide impact of public expenditures at a disaggregated level. However, some background studies do estimate the infrastructure deficit in Pakistan (Samad and Ahmed 2011).

World Bank (2007) reported that Pakistan's key infrastructure shortages lie in the water, irrigation, power and transport sectors. The country is amongst the most water-stressed in the world and rehabilitating current wear and tear in the water sector will require more than $\$ 7$ billion in maintenance over the next 5 years. Pakistan faces severe power shortages of approximately 5,000 MW and per capita energy consumption is among the lowest in the world, slowing industrial growth. The inefficiencies of the rail, road, port and aviation sectors are now costing the economy over $4 \%$ of GDP.

While various governments have tried to pump capital in maintenance and incremental infrastructure with the help of development partners, capacity to implement these programs has remained weak. The lack of suitable human resources, poor planning and management skills and an inability to attract external implementation resources has led to time and cost overruns. Over half of the annually trained engineers migrate abroad for employment (due to significant wage differences) and declining economic growth has made it impossible to attract them back (Mehmood et al. 2013). Corruption in infrastructure projects has been estimated to be 10-15\% of the project value. The average project runs three times longer and two times more expensive than the initially planned cost (Pasha 2011). This is attributed to: external verifications (National Accountability Bureau, Chief Minister's Inspection Teams, Parliamentary Committees etc.); audit procedures; local government procedures (mining, land acquisition, forest department etc.); law enforcement agencies; and corruption.

ADB (2008) explains that Pakistan had a successful experience with privatization of state-owned telecom enterprise. This not only attracted foreign direct investment but also ensured efficiency through competition. However, excessive regulation has impeded replication of this experience across other sectors, such as energy, where the government continues to subsidize operations. Also see SBP (2007) for more details in this regard. JBICI (2007) describes how productivity is declining among $45 \%$ of workers, primarily in the agricultural sector, due to the dilapidated state of irrigation infrastructure. The report shows that access to irrigation infrastructure helps to keep the incidence of chronic poverty at lower levels. Furthermore, improving, lining and upgrading watercourses will help improve water efficiency.

Pakistan faces a major threat from climate change. The country has witnessed regular instances of floods, droughts and earthquakes. The Asian Development Bank, World Bank and the One UN office jointly conducted the damage assessment 
for the 2010 floods and reported aggregate damages of PKR 855 billion. The reconstruction costs (which includes rebuilding/renovating lost infrastructure) range from an estimated US\$6.8 to 8.9 billion. The report recommends that this should be seen as an opportunity to build stronger and energy efficient infrastructure for future growth and welfare.

\section{Recent Issues}

Infrastructure affordability: Sustaining infrastructure growth has been difficult for developing countries over the medium to long run. Lin (2011) identifies three reasons for the slowdown of infrastructure growth in China after 1978. These include: low government spending, decreased investment incentives for state enterprises and diminished ability of local government to mobilize rural resources. Alternative infrastructure financing mechanisms mentioned by the authors include domestic and foreign debt, taxes, fees and user charges, profits of state enterprises and labour services.

Complementary Reforms: Dodonov et al. (2002) analyze transition countries (with special reference to Ukraine) and show that infrastructure reforms in these countries should be linked with tariff reforms along with an overall national policy of open commercialization and deregulation of infrastructure sectors. A failure to do so may prevent absorption of public and private funds into infrastructure development.

Macroeconomic stabilization: Increased globalization has rendered many developing countries prone to terms of trade shocks. The usual prescription given by multilateral organizations for countries finding themselves in balance of payments difficulties is contradictory fiscal policy. Ramirez (2004) questions stabilization policies in developing countries which disproportionately reduce public infrastructure spending in order to comply with reductions in fiscal deficits.

General equilibrium effects: It is important to note the relative superiority of general equilibrium models in studying the economy-wide, sectoral and disaggregated impacts of infrastructure investment and endowment. Several studies providing such important insights should be mentioned here: Giesecke et al. (2008) who study macroeconomic outcomes under alternative public infrastructure financing arrangements (also see Boccanfuso et al. 2012); Adam and Bevan (2006) look at the role of aid in public investment and possible Dutch disease effects (also see Levy 2007). 
Table 1 Global infrastructure ranking, 2011-2012

\begin{tabular}{|c|c|c|c|c|c|c|c|}
\hline & Transport & $\begin{array}{l}\text { Electricity and } \\
\text { telephony }\end{array}$ & ICT & Education & Health & Security & $\begin{array}{l}\text { Public } \\
\text { institutions }\end{array}$ \\
\hline Malaysia & 14 & 48 & 57 & 91 & 52 & 48 & 32 \\
\hline China & 29 & 69 & 74 & 93 & 71 & 68 & 46 \\
\hline India & 35 & 116 & 117 & 109 & 109 & 89 & 72 \\
\hline Sri Lanka & 52 & 79 & 100 & 89 & 61 & 59 & 49 \\
\hline Pakistan & 80 & 126 & 111 & 126 & 111 & 137 & 111 \\
\hline Philippines & 104 & 101 & 93 & 83 & 97 & 117 & 112 \\
\hline Benin & 115 & 118 & 120 & 123 & 120 & 95 & 91 \\
\hline Bangladesh & 117 & 137 & 132 & 118 & 107 & 103 & 112 \\
\hline
\end{tabular}

Source: Global competitiveness report, 2011-2012

\section{State of Infrastructure in Pakistan}

Infrastructure provides a backbone that sets an economy on the path towards sustained economic growth. The provision of basic and efficient infrastructure in transport, communications and utilities such as electricity provides an enabling environment for the private sector which then takes the lead in the growth process. Table 1 paints a dismal picture for Pakistan in terms of its global infrastructure ranking. While Pakistan has invested in public assets, poor governance (poor accountability, monitoring, stakeholder participation, etc.) continues to plague these assets (Planning Commission 2011).

Infrastructure in Pakistan was traditionally financed through public sector financing, much of which was actually leveraged through foreign aid. However given the rise in global commodity prices, and in particular its effects on input costs in the construction sector, it became almost impossible for the government to afford the rising unit cost of infrastructure financing. In the late $1990 \mathrm{~s}$, it was realized that Pakistan would not even be able to maintain the existing infrastructure without deregulating, privatizing and liberalizing this sector for domestic and foreign private investment. In absolute terms, these measures did increase capital formation in the transport and communication sectors.

\section{Road Transport}

For transportation, Pakistan relies heavily on roads which handle $96 \%{ }^{2}$ of total freight traffic. ${ }^{3}$ The federal budget also exhibits a strong bias towards financing construction and maintenance in the road sector. Since 1996, the total length of roads has increased by $13 \%$ to $259,618 \mathrm{~km}$ in $2010,179,290$ of which were paved

\footnotetext{
${ }^{2}$ Economic Survey of Pakistan, 2009-2010.

${ }^{3}$ This section draws from our companion paper Haque et al. (2011).
} 
(referred to as high type). The national highways and motorways network constitutes $4.2 \%$ of the total road network and handles more than $85 \%$ of all road traffic in Pakistan. The majority of Pakistan's highways and motorways network is along the North-south corridor with the N-5 acting as the main artery and carrying $55 \%$ of inter-city traffic in the country. Around $60 \%$ of the network is in poor conditions. This is mainly due to poor maintenance, vehicle overloading, overinflated truck tires and the significant shift from railways to roads in both passenger and freight transport.

Over the past few years, there has been a gradual increase in the length of high type roads and a decline in low type roads (unpaved), with most low type roads being converted to high type (Table 2). The National Highway Authority (NHA) has been carrying out extensive road development projects: 30 new projects to extend the road network by $1,000 \mathrm{~km}$ inclusive of bridges, flyovers, and interchanges have started. The NHA has also managed to increase its toll revenue by $36 \%$ over the past year.

Another problem in road transportation is the corruption in the policing system. Traffic laws are lax in Pakistan and the policemen are often underpaid and have long working hours. Corruption is also rampant on the infrastructure development side of road transportation. Roads are often deliberately left weak, susceptible to rapid deterioration, so that contracts can be repeatedly given to the same people.

For the impact and transmission channels of how investment in road infrastructure leads to productivity, economic growth and poverty reduction, we can look to Montolio and Solé-Ollé (2009) and Fan and Chan-Kang (2005). In the case of Pakistan, see Siddiqui (2008) and Chohan et al. (2011).

\section{Rail Transport}

Railways around the world have an edge in long haul and mass transportation of both goods and passengers. In Pakistan, it was the primary mode of transport until the 1970s. Since then its share has declined due to the shift in government's preference towards road rather than rail transport. Over 2005-2010, budget expenditures on railways totalled just PKR 45.5 billion whereas for national highways it stood at PKR 155 billion. Its share of inland traffic has fallen from 41 to $10 \%$ of passengers and from 73 to $4 \%$ of freight traffic.

Timely and safe transportation of merchandise from the port in the south for delivery in the north is a major issue given the poor infrastructure in road, rail, warehousing, etc. After the creation of the National Logistic Cell (NLC) to clear the goods from Karachi port, Pakistan Railways (PR) has always found it difficult to maintain its historical position. In Table 3, we see a gradual decrease in the number of passengers and freight moved as well as the length of track and the number of wagons and locomotives. 
Table 2 Road sector in Pakistan, 1997-2009

\begin{tabular}{|c|c|c|c|c|c|c|}
\hline \multirow[b]{2}{*}{ Year } & \multicolumn{2}{|c|}{ High type } & \multicolumn{2}{|c|}{ Low type } & \multicolumn{2}{|l|}{ Total } \\
\hline & Length & $\%$ change & Length & $\%$ change & Length & $\%$ change \\
\hline 1997 & 126,117 & 6.5 & 103,478 & 3.6 & 229,595 & 5.2 \\
\hline 1998 & 133,462 & 5.8 & 107,423 & 2.5 & 240,885 & 4.9 \\
\hline 1999 & 137,352 & 2.9 & 110,140 & -4.4 & 247,484 & 2.7 \\
\hline 2000 & 138,200 & 0.6 & 105,320 & -2.4 & 240,340 & -2.9 \\
\hline 2001 & 144,652 & 4.7 & 102,784 & -3.7 & 249,972 & 4.0 \\
\hline 2002 & 148,877 & 2.9 & 98,943 & -1.4 & 251,661 & 0.7 \\
\hline 2003 & 153,255 & 2.9 & 97,527 & -2.2 & 252,168 & 0.2 \\
\hline 2004 & 158,543 & 3.5 & 95,373 & -4.1 & 256,070 & 1.5 \\
\hline 2005 & 162,841 & 2.7 & 91,491 & -5.6 & 258,214 & 0.8 \\
\hline 2006 & 167,530 & 2.9 & 86,370 & -2.7 & 259,021 & 0.3 \\
\hline 2007 & 172,827 & 3.2 & 84,038 & -1.1 & 259,197 & 0.1 \\
\hline 2008 & 175,000 & 1.3 & 83,140 & -3.4 & 259,038 & -0.1 \\
\hline 2009 & 177,060 & 1.2 & 80,328 & 2.5 & 260,200 & 0.4 \\
\hline
\end{tabular}

Source: Economic survey of Pakistan, 2009-2010

Table 3 Pakistan rail sector

\begin{tabular}{llll}
\hline Rail sector indicators & 1991 & 2009 & \% change \\
\hline Route travelled (km) & 8,775 & 7,791 & -11.2 \\
Passengers carried (millions) & 84.9 & 82.54 & -2.8 \\
Freight carried (million tonnes) & 7.72 & 6.94 & -10.1 \\
Locomotives & 753 & 551 & -26.8 \\
Freight wagons & 34,851 & 17,259 & -50.5 \\
\hline
\end{tabular}

Source: Pakistan Railways 2011

A significant reduction in business activity during the last year partially attributable to security issues, ultimately reducing government revenues. There has also been a shortage of active locomotives due to non-procurement of spare parts. Much of the rolling stock damaged during the December 2007 riots has yet to be repaired. This delay has been mainly due to a reduction in Public Sector Disbursement Program disbursements and slow corporatization. The majority of the engines recently acquired from China are also facing maintenance issues leading to closure of several routes. Earnings are still low and are hardly enough to cover the cost of salaries and pensions, respectively equal to PKR 14 billion and PKR 7 billion per annum. In 2008-2009, earnings grew by $16 \%$ compared to the year before but since have worsened to pre-2004 levels. Despite improved performance during the last decade, losses remain high, at PKR 10 billion in 2006-2007 and over PKR 12 billion in 2007-2008. ${ }^{4}$

\footnotetext{
${ }^{4}$ For detailed discussion of the growth and productivity effects of rail infrastructure investment, see Crafts (2011) and Banister and Thurstain-Goodwin (2010).
} 


\section{Aviation}

In 2007-2008, Pakistan's 35 airports handled more than 14 million passengers and 318,652 million tons of cargo. ${ }^{5}$ Jinnah International Airport in Karachi is the busiest, but the Lahore and Islamabad airports also handle significant amounts of domestic and international traffic.

Compared to 2005-2006, both cargo and passenger traffic have fallen. Total passenger traffic has declined by 0.4 million passengers and cargo traffic decreased from 347,674 to 318,652 million tons. Most of this is attributed to the reduction in domestic traffic associated with the poor situation regarding the economy, political instability and law and order.

The total number of domestic and international airlines operating in Pakistan (28) remained the same, although two Pakistani airlines (Aero Asia and Royal Airlines) are no longer in business. This is attributed not only to mismanagement but also to the government's close association with state-owned Pakistan International Airlines (PIA) and the uncompetitive environment for other domestic airlines. PIA accounts for $73 \%$ of all passenger traffic and captures nearly the entire market for freight in the aviation sector. International routes are covered by frequent flights to the UK and Middle Eastern countries. Demand on these routes mainly comes from Pakistani workers abroad. Connections to other countries generally remain infrequent and time consuming.

Due to extra security checks on airlines flying via Pakistan and the recent slowdown in the aviation sector, international airlines largely remain hesitant to explore the Pakistani market. Currently, no Pakistani airline flies direct to any African or Latin American country and the only flights connecting the country to Southeast Asia are two direct flights per week to Malaysia. Connecting flights to other destinations are available but it takes much longer and arrival times are highly uncertain.

Domestic connectivity is also constrained by inadequate airport handling and slow check-in procedures. This leads to lengthy flight delays, making air travel highly inconvenient, particularly given the much higher ticket prices. The domestic market is strong dominated by PIA as a result of preferential route allocation, tax benefits and other protectionist policies, making it difficult for new carriers to enter the aviation sector. ${ }^{6}$

\footnotetext{
${ }^{5}$ Civil Aviation Authority. http://www.caapakistan.com.pk/, access October 12th, 2012.

${ }^{6}$ For discussion on how air transport infrastructure investment facilitates economic growth, see Hong et al. (2011) and Marazzo, Scherre and Fernandes (2010). For Pakistan see Haque et al. (2011).
} 
Table 4 Electricity production (megawatts)

\begin{tabular}{llc}
\hline Year & Installed capacity (MW) & Generation (MW) \\
\hline $2001-2002$ & 17,799 & 8,265 \\
$2002-2003$ & 17,798 & 8,639 \\
$2003-2004$ & 19,257 & 9,235 \\
$2004-2005$ & 19,384 & 9,787 \\
$2005-2006$ & 19,450 & 10,705 \\
$2006-2007$ & 19,420 & 11,231 \\
$2007-2008$ & 19,420 & 10,943 \\
$2008-2009$ & 19,786 & 10,484 \\
July-March & & \\
2008-2009 & 19,575 & 6,940 \\
2009-2010 (e) & 19,650 & 7,517 \\
\hline
\end{tabular}

Source: Economic survey 2009-2010

\section{Energy}

Pakistan has been facing significant energy shortages since 2008-2009. The main issue has been the complicated market structure, not capacity constraints. Between 2003 and 2007, energy prices were held fixed, making the private sector more dependent on government subsidies to accommodate variable production costs. Sharp increases in oil and gas prices throughout 2008 put enormous upward pressure on cost structures in the power generation sector. Since tariffs also remained unchanged, much of this burden had to be borne by the government in the form of increased subsidies. However, rising costs in the war on terror along with a slowdown in GDP growth reduced government resources, ultimately leading to the emergence of the inter-corporate debt problem.

Table 4 shows that electricity generation began to decline from 2006 to 2007 onwards despite an increase in overall installed capacity during the same period. Fortunately, data for the last 2 years (shown only for July-March in these 2 years) shows a positive trend.

Despite frequent increases in electricity tariffs in the last 2 years, a wide gap still exists between generation cost and recovery. Before the increases in tariffs, this gap was estimated at around $30 \%$. Steps towards elimination of subsidy-based tariff regime have helped reduce inter-corporate debt to 120 billion PKR as of May 2010 compared to 216 billion rupees in June $2009 .^{7}$

\footnotetext{
${ }^{7}$ The link between demand for energy and economic growth has been studied at length in Lee and Chang (2008), Apergis and Payne (2009) and Wolde-Rufael (2008). For Pakistan's case see USAID (2007) and Hye and Riaz (2008).
} 


\section{Water and Sanitation}

The quality of physical infrastructure continues to deteriorate and its coverage is exceedingly inequitable; the poor stand deprived and disadvantaged, and pay exorbitant prices to water vendors. The present coverage of water and sanitation facilities are respectively said to be 85 and $65 \%$ in urban areas, but the accuracy of these statistics is often questioned.

Management of service delivery is also a big issue. An important deficiency in this regard has been a lack of local government capacity to generate enough funds for the operation and maintenance of existing networks. There are often no incentives for improved operations and management (O\&M) and assets tend to deteriorate much earlier than their usual life. For major projects, local governments are dependent on the assistance of provincial and federal governments. Public sector investment in the sector is very low, at $0.25 \%$ of GDP. In spite of the government's interest in and encouragement of private sector involvement, its' participation has been low.

Local governments suffer technical, financial and administrative weaknesses in planning and in operations and maintenance-related issues, especially in relation to energy requirements. These local government departments are both overstaffed and have an insufficiently trained workforce.

Moreover, underground water reserves are depleting rapidly due to high withdrawal and surface water is exposed to municipal discharges and pollution. Cities have increasingly scarce and poor quality water supplies. Meanwhile, a full $35-40 \%$ of water supplies are lost through leakages in water distribution networks. Water treatment facilities are also limited.

Sewage is collected through open drains in most cities, and is then discharged untreated into rivers, streams, lakes and canals. These waterways are often used as sources for urban water supply schemes. Collection through piped networks is limited to few large cities where coverage is also selective and sewage treatment rare. In small towns, open defecation is not uncommon.

Only $5 \%$ of households have proper access to municipal garbage collection systems, and arrangements to dispose of this waste at properly developed landfill sites are often lacking. Uncollected garbage accumulates in the streets and in open spaces between houses, where scavengers extract the reusable and recyclable materials and leave the rest to rot. $^{8}$

\section{Government Infrastructure Strategy}

Given low domestic resource mobilization and low expected tax revenues, public investment has been consistently declining. The existing public sector development programme allocates a very high share of its resources to civil work (almost $60 \%$ in

\footnotetext{
${ }^{8}$ Discussion on investment in the water sector and its impact on economic growth may be seen in Barrios et al. (2010) and Grey and Sadoff (2007). In case of Pakistan, see World Bank (2008).
} 
2011), leaving little for social sectors such as education and health. Public investment has been spread thin across sectors and regions, making it difficult to focus strategy. The governance of public investment also requires immediate attention. Issues such as electricity and gas shortages result from management problems, not capacity limitations.

The government has been advised to unbundle service delivery of most public utilities. Public investment should be prioritized and sequenced. Public sector projects nearing completion should be given priority. Key infrastructure projects for energy, water and transport production inputs will require participation of the private sector, so rules for public private partnerships should be made as straightforward as possible. Finally, projects to remove regional disparities should be initiated, potentially enabling greater labour force participation, particularly in war torn areas.

Due to the fiscal crunch and a lack of coordination between government departments, the National Trade Corridor project was abandoned in 2011. The project had earlier been envisaged as having an integrated focus on transport, logistics and economic growth. The Planning Commission (2011) realized that resource constraints meant that new investment in infrastructure was hard to come by, and that the government should thus shift focus more toward improving management of existing infrastructure. To some extent, this remains true as many public sector monopolies in the provision of infrastructure have underperformed due to structural inefficiencies. This document also talks about deregulating the rail, road and aviation sectors to allow private sector participation. Interest has already been expressed by China, India and other East Asian economies for direct investments in transport, logistics, and oil and gas exploration.

It is pertinent to mention that autonomous or semi-governmental bodies such as WAPDA, OGDCL, etc., outline their own investment plans according to their own resource availability and projected cash flows. Provincial governments also spend directly on infrastructure; some have outlined their infrastructure priorities in provincial economic reports.

\section{Data and Parameterization}

The CGE-microsimulation approach adopted for this study is discussed in chapter on The Philippines case study. For more details, refer to Dissou and Didic (2011) for the CGE model and to Cockburn et al. (2011) for the microsimulation module.

The dynamic CGE model is calibrated to the benchmark data in the 2007-2008 Pakistani social accounting matrix, where 12 production sectors and 12 commodities are identified. For the microsimulation model we use the Pakistan Social and Living Standards Measurement Survey (PSLM) 2007-2008. Some of the external parameters used in the CGE model include: substitution elasticity of the CES household function $(0.7 \%)$, substitution elasticity of first- and second-level CES production functions $(0.5 \%$ and $0.4 \%)$, the depreciation rate $(12 \%)$, output elasticity of 
public capital (0.3), the share of public investment in total investment $(28 \%)$, the population growth rate $(1.8 \%)$, the world real interest rate $(6 \%)$ and the share of constrained households in: consumption (57\%), labour income (71\%), income taxes $(10 \%)$ and government transfers $(10 \%)$. Most of these external parameters are in line with previous CGE studies on Pakistan (such as Ahmed and O' Donoghue 2010). For details on comparable discussion of parameters, please see UNIDO (2009).

Simulation design: We simulate a $4 \%$ increase in the public infrastructure investment-to-GDP ratio. This increase brings the public infrastructure investmentto-GDP ratio back to the levels observed prior to the food, fuel and financial crises. This simulation follows the Planning Commission's Framework for Economic Growth by studying the impact of a $4 \%$ increase in this ratio financed by either (a) international borrowing or (b) a production tax. ${ }^{9}$ We look at the short, medium and long term impacts in both of these policy experiments. ${ }^{10}$

\section{Results}

Financing the $4 \%$ increase in the public infrastructure investment-to-GDP ratio by an increase in international borrowing generates a real GDP growth higher right from the very first period because foreign savings finance the borrowing used to increase investment, with a $1.3 \%$ growth in the overall long-run. If we disaggregate by GDP components, total investment and household consumption in the long run are simulated to grow by 3.4 and $1.2 \%$ respectively (Table 5).

Infrastructure investment appears to have redistributive effects, given that the rise in consumption is relatively higher among constrained households than non-constrained households. Additionally, constrained firms in this scenario invest more starting in the first period (again reflecting increased savings available for investment purposes).

Wages rise throughout the time horizon, while the price of capital declines over time. The lower cost of capital facilitates long run expansion of both public $(+5 \%)$ and private $(+2 \%)$ capital stocks. In the long-run, the private capital stock increases by relatively more among non-constrained firms due to their access to financial services.

\footnotetext{
${ }^{9}$ The reason for choosing the production tax is that usually, of the many indirect taxes, this is one of the easiest to implement in developing countries with fewer politically unfavorable implications (given that it is linked with growth in value added). However this tax also has highly distortionary effects on production and consumption.

${ }^{10}$ All variables are expressed in "per efficient workers" terms (per capita + technological progress). If we suppose that in the business as usual (BAU) scenario all variables rise by the population growth and technological progress rates, and if we express all variables in "per efficient workers," then under the BAU variables are constant over time and correspond exactly to the base year. All results presented below should thus be read as changes relative to the base year.
} 
Table 5 Macro impacts of $4 \%$ increase in public infrastructure investment-to-GDP ratio (international borrowing), percentage change wrt base scenario

\begin{tabular}{lccc}
\hline Variable & First period & Short run & Long run \\
\hline Real GDP & 0.31 & 0.69 & 1.29 \\
Wage rate & 0.23 & 1.04 & 2.26 \\
Price of capital goods & 0.39 & 0.35 & 0.08 \\
Rental rate of capital, constrained households & 0.69 & 1.43 & 1.31 \\
Total household consumption & 0.07 & 0.46 & 1.16 \\
Constrained & 0.45 & 0.93 & 1.58 \\
Non-constrained & -0.07 & 0.04 & 0.37 \\
Total Investment & 1.65 & 2.33 & 3.35 \\
$\quad$ Public & 3.92 & 4.35 & 5.26 \\
Private & 0.75 & 1.52 & 2.59 \\
Constrained & 0.06 & 0.58 & 1.50 \\
Non-constrained & 1.05 & 1.93 & 3.07 \\
Total capital stock & & 0.85 & 2.81 \\
$\quad$ Public & & 1.81 & 4.64 \\
Private & & 0.44 & 2.01 \\
Constrained & & 0.13 & 1.13 \\
Non-constrained & & 0.59 & 2.45 \\
Total exports & -0.50 & 0.23 & 1.80 \\
Total imports & 0.84 & 1.31 & 1.93 \\
Real exchange rate & -0.28 & -0.24 & -0.03 \\
Foreign savings as \% of GDP & -2.73 & -2.74 & -2.83 \\
Total income of constrained households & 0.45 & 0.93 & 1.58 \\
Labour income & 0.23 & 1.04 & 2.26 \\
Capital income & 0.69 & 1.57 & 2.45 \\
Government revenues & 1.63 & 2.03 & 2.55 \\
Additional foreign borrowing as \% of GDP & 0.21 & 0.17 & 0.09 \\
\hline Sorce Auth computation based on & & &
\end{tabular}

Source: Authors' computation based on simulation results

On the trade side, the increase in foreign reserves leads to real exchange appreciation. In the first period, this reduces export price competitiveness, indicating a Dutch disease-like effect. In the first period, exports decline by $0.5 \%$ and imports increase by $0.84 \%$. In the long run, both exports and imports increase because greater availability of investment funds and a higher stock of infrastructure improve supply side conditions. The increase in the international borrowing-toGDP ratio tapers off (declining by $0.09 \%$ in the longer run) due to reduced borrowing needs to fund incremental infrastructure. This is also attributable to rising government revenues in the long run. The increase in government revenues is higher in the long run (by $3 \%$ ) than in the previous simulation because foreign savings have a greater growth impact. The main sources of additional revenue are direct taxes, consumption taxes and import taxes.

Gross output grows by most in the construction and non-textile manufacturing sectors (which are relatively labour intensive), followed by cotton and textiles which are export-oriented sectors (Table 6). Prices decline across the board in the longer run (Table 7), partially explaining the gains in household consumption. 


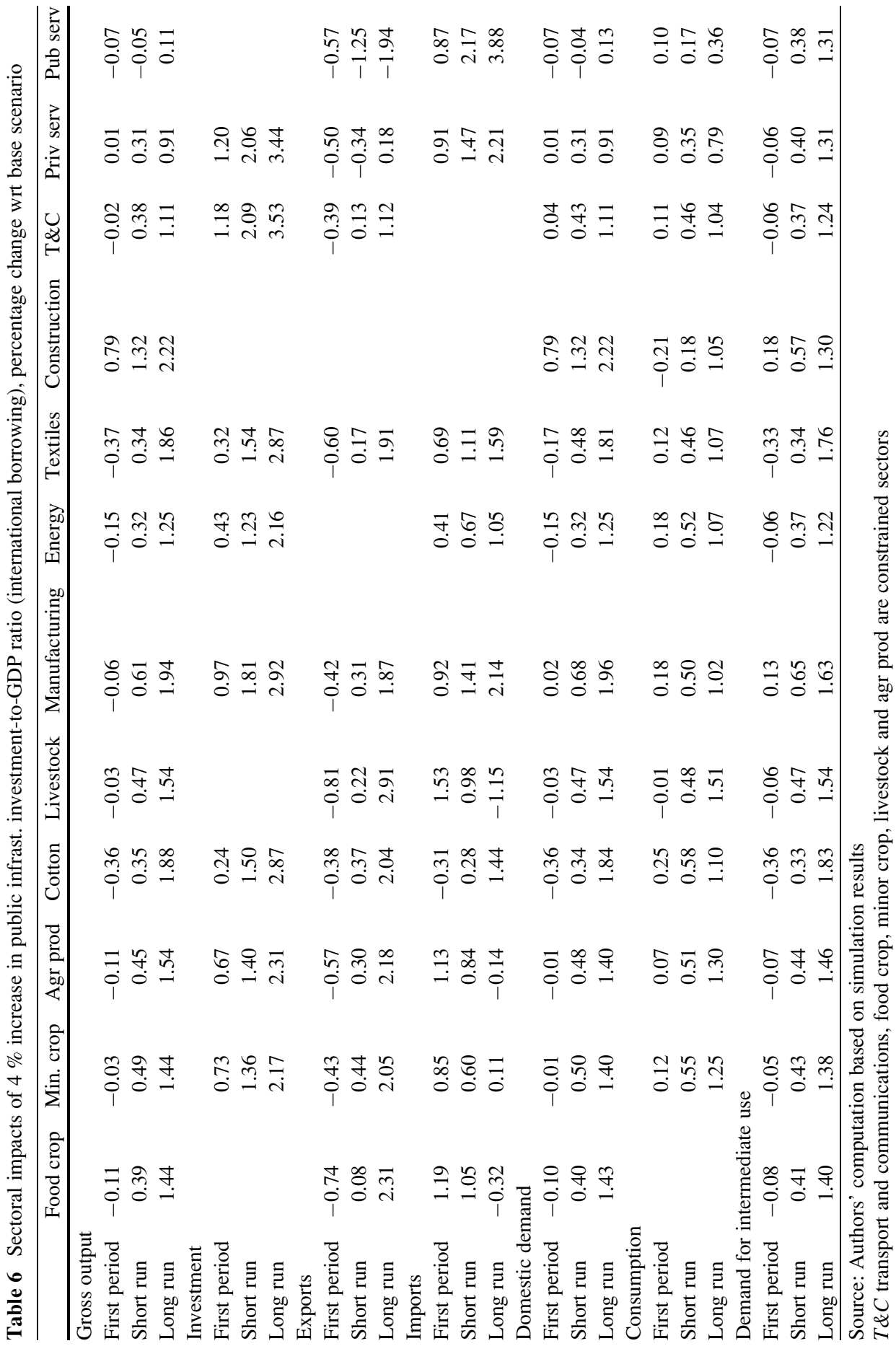




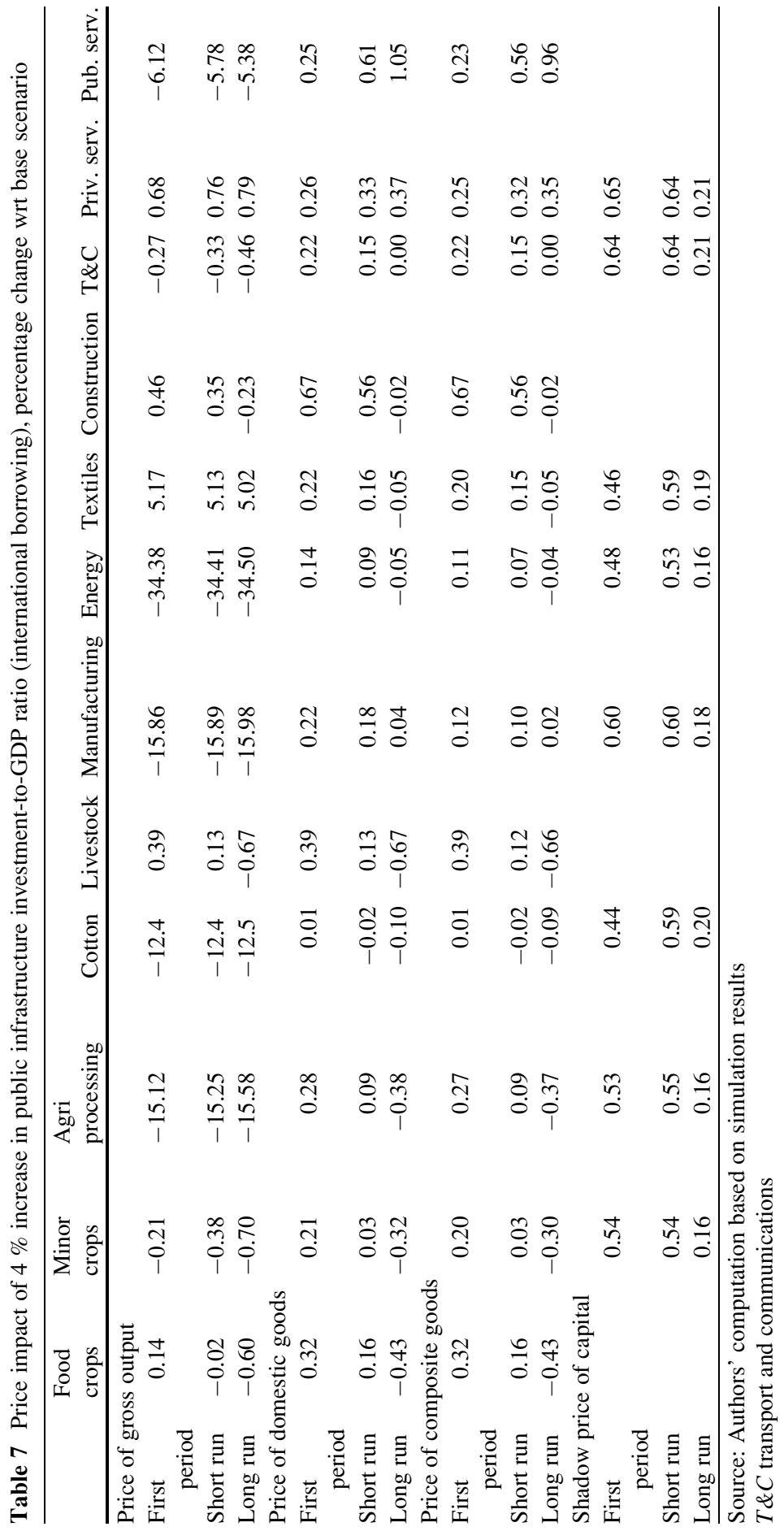


Under a policy experiment of infrastructure financed through international borrowing, poverty reduction can be observed from the very beginning (Table 11), with higher wages contributing the most to poverty reduction, followed by increased self-employment incomes (Table 12).

Poverty is lower in the long run among both household types, but the relative improvements in the poverty headcount are higher among constrained households (Table 13). The provincial poverty incidence results show that poverty reductions are greatest in the Punjab and Sindh provinces (Table 14). The international borrowing scenario is redistributive, with inequality falling throughout the time horizon (Table 15).

Unlike the previous simulation, financing the $4 \%$ increase in the public infrastructure investment-to-GDP ratio by an increase in taxes strains real GDP growth in the first period $(-0.06 \%)$. However, growth recovers in the short-run (within 5 years) and is $1 \%$ higher than the baseline scenario in the longer-run (Table 8), but below the rates predicted for the international borrowing scenario along the whole simulation timespan. Total consumption follows a similar pattern: the increased tax burden causes total household consumption to decline by $0.1 \%$ in the first period, but is $0.94 \%$ higher in the longer run. As in the previous simulation, total household consumption is redistributed somewhat, with increased taxes implying greater gains for constrained households $(1.2 \%)$ than for non-constrained households $(0.2 \%)$, which have access to savings instruments. This is primarily due to an increased incidence of tax on non-constrained households who own enterprises facing the distortionary production tax. This tax mostly affects large manufacturing firms, which are mostly in food processing-, textiles- and construction-related industries.

The main increase in overall investment comes from public investment, which is $5 \%$ higher in the longer run. There are also positive knock-on effects on private investment, which increases by $2.3 \%$, providing evidence of a crowding-in effect. ${ }^{11}$ In the private sector, investment by non-constrained firms is $2.7 \%$ higher in the long run. While constrained firms also gain in the short run and beyond, their investment declines by $0.27 \%$ in the first period. This can be attributed to the lagged transmission of the increase in overall pool of savings to be used for investments by constrained firms, which in the model are assumed to be financed by own retained earnings. ${ }^{12}$

The price of capital and labour move in opposite directions whereby the former increases in the short run but declines in the long run, in turn resulting in greater capital formation. ${ }^{13}$ This may be attributed to the increased tax burden which

\footnotetext{
${ }^{11}$ It is important to note that private investment is higher despite a production tax due to complementarities in public and private investment. However, in the short term there is a negative impact on private investment at the disaggregated level and a null effect on the capital stock.

${ }^{12}$ The positive externality of public investment in terms of expansion in private capital stocks is around $1.7 \%$ in the long run.

${ }^{13}$ The complementarity of private capital linked to the public capital rises and this produces an implicit surplus of private capital in the long run, thus pushing the price or returns to private capital downwards. Also, labour becomes relatively more rare, pushing wages upwards.
} 
Table 8 Aggregate impacts of $4 \%$ increase in public infrastructure investment-to-GDP ratio (tax financing), percentage change wrt base scenario

\begin{tabular}{lrrr}
\hline Variable & First period & Short run & Long run \\
\hline Real GDP & -0.06 & 0.33 & 1.01 \\
Wage rate & -0.32 & 0.51 & 1.86 \\
Price of capital goods & 0.12 & 0.14 & -0.02 \\
Rental rate of capital, constrained households & 0.02 & 1.02 & 1.24 \\
Total household consumption & -0.11 & 0.25 & 0.94 \\
Constrained & -0.15 & 0.38 & 1.19 \\
Non-constrained & -0.09 & -0.04 & 0.18 \\
Total Investment & 1.29 & 1.99 & 3.07 \\
$\quad$ Public & 3.81 & 4.19 & 5.07 \\
$\quad$ Private & 0.29 & 1.11 & 2.27 \\
Constrained & -0.27 & 0.24 & 1.21 \\
Non-constrained & 0.54 & 1.50 & 2.74 \\
Total capital stock & & 0.71 & 2.53 \\
$\quad$ Public & & 1.76 & 4.47 \\
Private & & 0.26 & 1.69 \\
Constrained & & -0.02 & 0.84 \\
Non-constrained & & 0.40 & 2.11 \\
Total exports & -0.19 & 0.45 & 1.88 \\
Total imports & 0.37 & 0.89 & 1.58 \\
Real exchange rate & 0.03 & 0.01 & 0.12 \\
Foreign savings as \% of GDP & -2.68 & -2.70 & -2.82 \\
Total income of constrained households & -0.15 & 0.38 & 1.19 \\
Labour income & -0.32 & 0.51 & 1.86 \\
$\quad$ Capital income & 0.02 & 1.00 & 2.09 \\
Government revenues & 1.18 & 1.62 & 2.26 \\
Increase in production tax rate $(\%)$ & 3.43 & 3.03 & 1.73 \\
\hline Source: Auth compution & &
\end{tabular}

Source: Authors' computation based on simulation results

${ }^{\mathrm{a}}$ In case of CGE results long run represents a 60 year period

reduces retained earnings in the short run, although the increase in public investment afforded by increased taxation in the longer run leads to greater capital formation and ultimately economic growth through a multiplier effect. The wage rate slumps by $0.32 \%$ in the first period, recovers in the short run and is nearly $2 \%$ higher in the longer run. The differences in the increased usage of production factors can also be attributed to the distortionary effects of the increased production tax.

The external balance, measured as foreign savings as a ratio of GDP, remains in the vicinity of $3 \%$. The key changes are seen in the trade account. Despite real exchange rate depreciation, exports decline sooner due to supply side losses resulting from the higher tax burden. Following a $0.2 \%$ decline in the first period, exports recover by $2 \%$ in the long run. The trade deficit narrows somewhat in the long run (by $2.6 \%$ ) because imports grow more slowly.

The overall increases in household and corporate incomes, private consumption, value added in the manufacturing sector and imports, cause government revenues to 
increase by $1.2 \%$ in the first period and by $2.3 \%$ in the long run. Income, consumption, value added and imports are all taxed at various stages and thus contribute to government revenues.

It is important to look into the sectoral impacts of changes in GDP components (Table 9), as gross output in most sectors decreases in the first period, but recovers in all sectors in the long run. Expanded output also contributes to declining prices in the long run. Most of this follows the underlying trend of lower consumption (due to the increased tax burden) except in the manufacturing and construction sectors. Total investment increases in all sectors in the first period, except in the energy sector where it recovers in the short run.

Exports increase in most sectors in the first period, except in non-textile manufactured items, processed food and cotton, which see a decline in exports. Exports of non-textile manufactured items also remain below their baseline value in the short run, but do grow by $1.5 \%$ in the long run. The negative growth in exports of public services can be explained by the fall in transport and logistics services provided by Pakistan to other countries seeking transit, in particular foreign governments seeking to access Afghanistan through Pakistan. ${ }^{14}$

Domestic prices decline in most sectors except for the cotton, non-textile manufacturing and energy sectors (Table 10). Since these types of goods make up a relatively larger share of the household budget among the poor, lower prices have a redistributive effect, reducing inequality.

We now look at the poverty impacts of tax-financed public infrastructure. Unlike the previous simulation, this production tax is distortionary, adversely affecting the poverty headcount in the first period through reduced consumption and income. Increased infrastructure eventually helps expand supply and lower prices, restoring consumption and investment growth and thereby improving poverty levels. In Table 11, we can see that poverty is $0.3 \%$ lower in the long run (20 years in our microsimulation). The change in poverty is statistically significant at the $95 \%$ confidence level. ${ }^{15}$

We also see in Table 12 that increased wages and proceeds from selfemployment are the main drivers of poverty reduction. Constrained households see a greater reduction in their poverty levels over the long run (Table 13), as partially reflected by the higher increase in real consumption among

\footnotetext{
${ }^{14}$ Other items are counted under public sector services exports, transport and logistics services dominate.

${ }^{15}$ CGE results (regarding quantitative variables) are provided to the micro model in productive worker terms (it then takes into account the change in population, labour and technology). This approach allows us, though not fully satisfactorily, to leave the original micro-data unchanged. Then, changes in savings are introduced into the micro model by plugging in results obtained in the CGE model. Also, the macro model did not distinguish workers by skill and sector (full mobility across sectors), so the micro framework did not model the evolution in education/skills and labour mobility. Finally, for simplicity and lack of satisfactory information in the household survey, we made the hypothesis that capital endowments are fixed.
} 


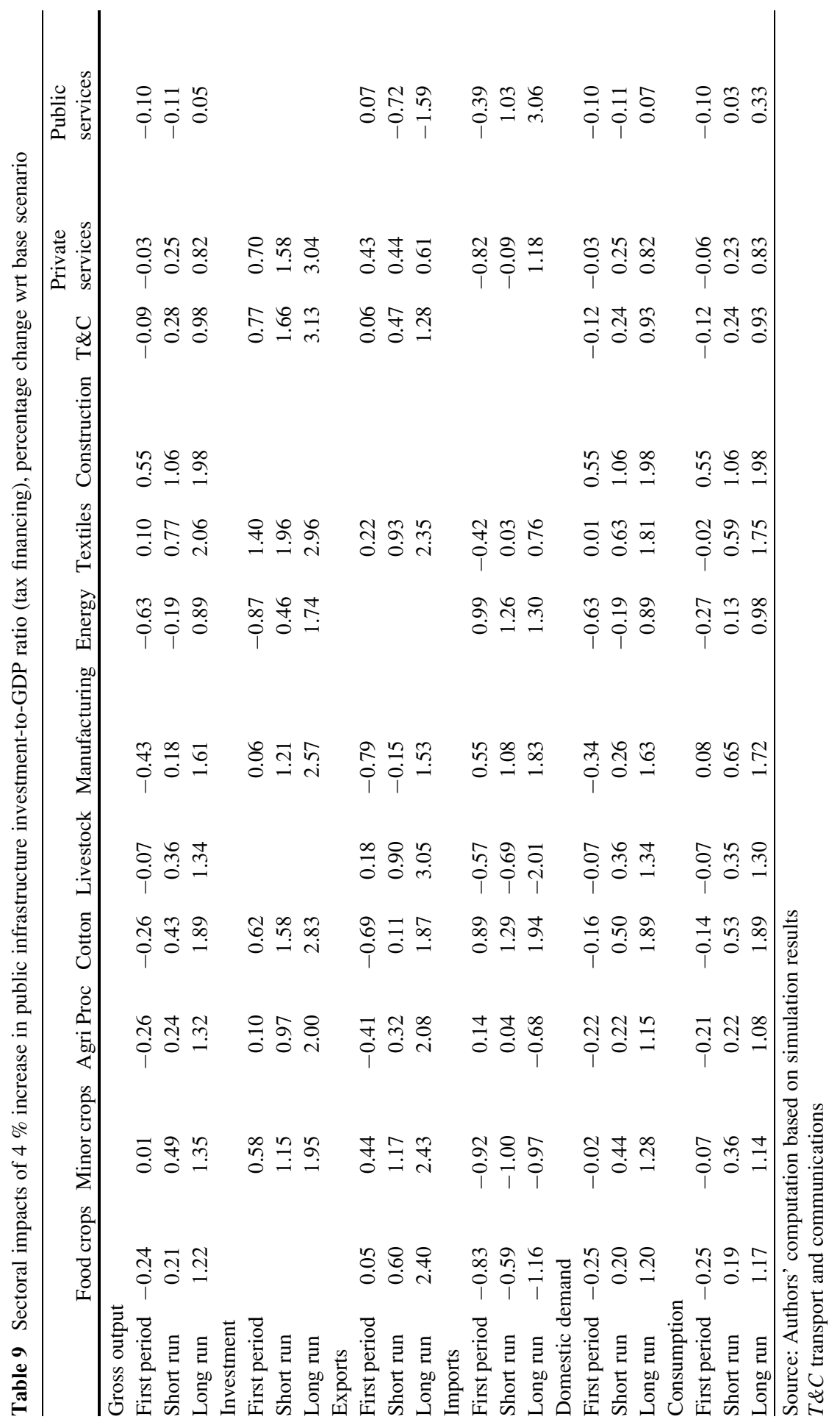




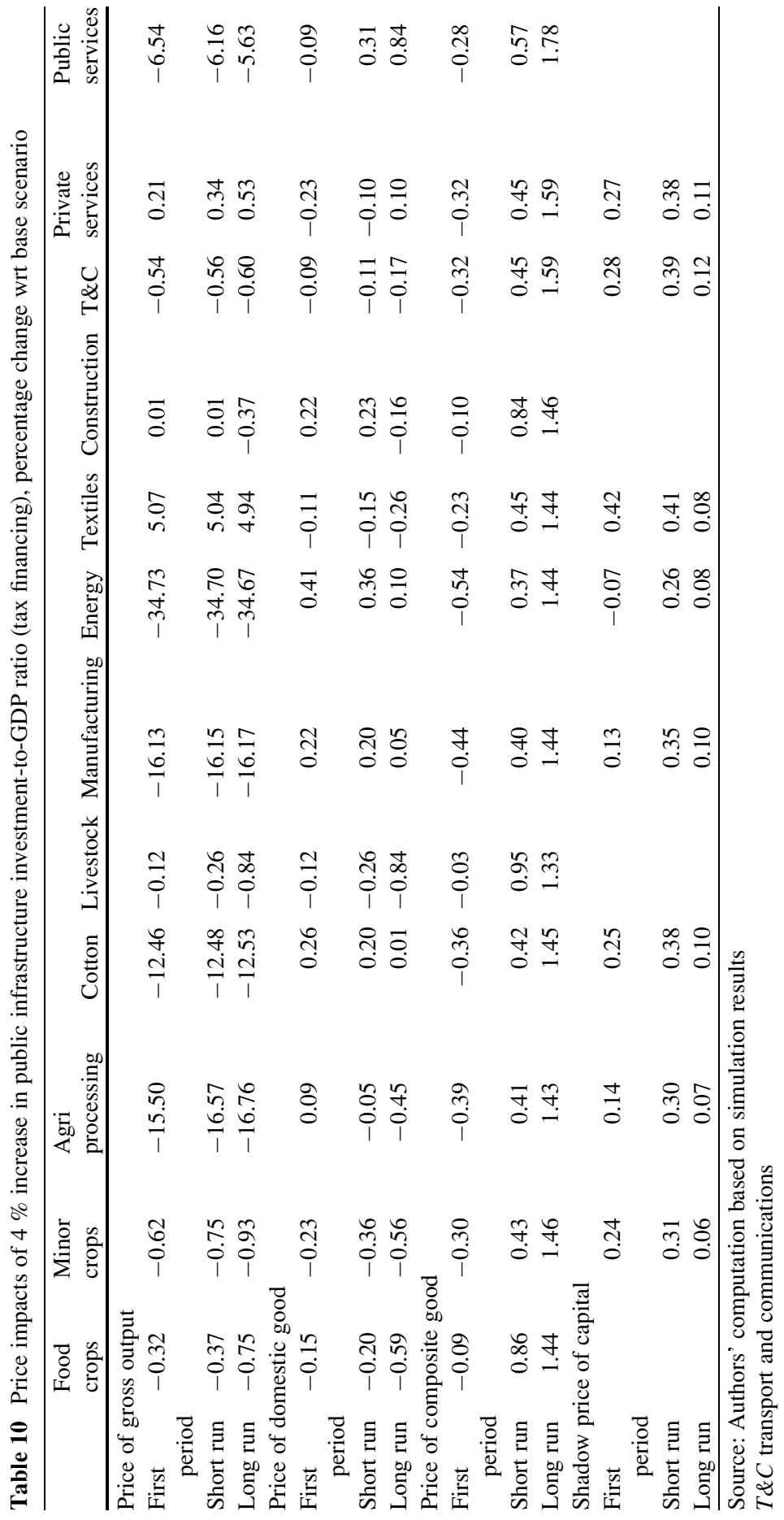


Table 11 Impact of $4 \%$ increase in public infrastructure investment-to-GDP ratio on poverty headcount, as \% from the base year

\begin{tabular}{llll}
\hline Simulation & 1 year & 5 years & 20 years \\
\hline International borrowing & -0.02 & -0.18 & $-0.40^{\mathrm{a}}$ \\
Tax financing & 0.012 & -0.09 & $-0.31^{\mathrm{a}}$ \\
\hline
\end{tabular}

Source: Authors' calculation based on simulation results

${ }^{\mathrm{a}}$ Indicates that the variation in comparison with the base year scenario is statistically different from zero (at $95 \%$ confidence interval)

constrained households. ${ }^{16}$ One could also argue on the income side (at the macro level) that the capital income of constrained households has increased relatively more than labour income. In the longer run, capital income has a greater multiplier impact on components of economic growth, implying that households are able to increase their retained savings for future consumption (or investment). ${ }^{17} \mathrm{~A}$ related point is that prices in the most important consumption categories for constrained households decreased faster (or increased less) and their main sources of incomes increased faster (or decreased less) than non-constrained households. In terms of provincial poverty levels (Table 14), we observe a similar progress in poverty reduction as observed in the previous simulation, with Punjab, followed by Sindh, showing the largest improvement. One way to explain this is that Punjab has the largest number of constrained households which, as stated above, are simulated as having a larger increase in real consumption. The Gini inequality coefficient is higher in the first year due to the distortionary tax, then improves due to wage increases in later periods (Table 15). We may conclude that infrastructure financing through increasing production taxes is more painful in the very short term.

Finally, with respect to the contribution of the own-consumption component to poverty reductions, we found no effect. This is an expected quantitative result when the changes in self-production and/or consumer prices are sufficiently negligible. In our case it seems to be a combination of both: three of four provinces have seen reductions in self-production stocks (explained below), in addition to the small magnitude of the price change.

The report by the Sustainable Development Policy Institute entitled Food Insecurity in Pakistan 2009 highlights that food security (including availability aspects) has deteriorated in 81 out of 131 districts of Pakistan. ${ }^{18}$ Around $49 \%$ of the

\footnotetext{
${ }^{16}$ It is important to note that we have used the classification of constrained and non-constrained households as we are interested in distinctly observing poverty and inequality effects on households with access to capital markets versus those without such access. This hypothesis is particularly pertinent in a developing country's context, where a lack of or barriers to credit access still represents a major obstacle in economic development. The constrained versus non-constrained distinction mirrors the difference in investment and savings patterns and finally results in differentiated impacts of public infrastructure investment on household welfare. In the longer term, access to financial services is expected to smooth consumption patterns.

${ }^{17}$ However labor income is a greater share of the overall incomes of non-constrained households.

${ }^{18}$ In 2003 , food security conditions were deemed inadequate in 45 out of 120 districts.
} 
Table 12 Long-run (20 years) impact of different factors on poverty headcount, as $\%$ from the base year

\begin{tabular}{lrr}
\hline Variable & International borrowing & Tax financing \\
\hline Wage employment & -0.25 & -0.24 \\
Self-employment & -0.20 & -0.11 \\
Consumer prices & 0.06 & 0.04 \\
Own-consumption & 0.00 & 0.00 \\
Residual & -0.01 & -0.00 \\
\hline
\end{tabular}

Source: Authors' calculation based on simulation results

Table 13 Change in poverty headcount by household type in the long-run (20 years), as $\%$ from the base year

\begin{tabular}{lll}
\hline Variable & International borrowing & Tax financing \\
\hline Constrained & -0.42 & -0.34 \\
Non-constrained & -0.38 & -0.27 \\
\hline
\end{tabular}

Source: Authors' calculation based on simulation results

Table 14 Long run (20 years) poverty reduction by province, as $\%$ from the base year

Table 15 Changes in Gini inequality coefficient, as \% from the base year

\begin{tabular}{lll}
\hline Type of households & International borrowing & Tax financing \\
\hline Punjab & -0.43 & -0.33 \\
Sindh & -0.40 & -0.30 \\
Khyber Pakhtunkwa & -0.35 & -0.26 \\
Balochistan & -0.33 & -0.25 \\
\hline
\end{tabular}

Source: Authors' calculation based on simulation results

\begin{tabular}{lccc}
\hline Simulations & 1 year & 5 years & 20 years \\
\hline International borrowing & -0.03 & -0.07 & -0.12 \\
Tax financing & 0.02 & -0.04 & -0.11 \\
\hline Source: Authors' calculation based on simulation results
\end{tabular}

Source: Authors' calculation based on simulation results

Pakistani population does not have access to sufficient food for an active living. There is evidence of inter and intra-provincial disparities. The report also explains that, between 2003 and 2009, wheat production rose by $6 \%$ in surplus-producing districts, but the percentage of surplus wheat available (which is usually exported) declined from $28.3 \%$ in 2003 to $17.5 \%$ in 2009 implying that the majority of provinces are now relying on external food sources. The above-mentioned phenomenon is also supported by the observation that wheat consumption has continued to decline because rising global crop prices effectively reduce purchasing power for wheat. In 2009 alone, wheat consumption declined by $10 \%$.

The report goes on to discuss at least two important implications of the high food prices and declining returns to farm activities with respect to the reduction in own-consumption. First, rising crop prices mean that the poorest farming households have squeezed their own-consumption stocks and traded them for short term monetary gains. Second (and related to first point) the coping strategy in both urban and rural areas is to meet caloric requirements from less preferred and less expensive food. 
Finally, it is important to mention that in a quantitative exercise such as this one the direction of change in key macro and microeconomic variables is more important that the magnitude. While both simulations point towards greater prospects for growth and poverty reduction due to increased infrastructure investment, the choice between taxation and international financing (borrowing) will also involve difficult political considerations.

\section{Conclusion}

In this chapter we use a dynamic CGE model linked with a microsimulation model to estimate the macro-micro impact of public infrastructure investment. In the model we have made a distinction between constrained households and firms (who are constrained by their lack of access to credit and savings instruments) and non-constrained households and firms who are fully integrated into the open economy and have access to both domestic and international capital.

Two approaches to public investment are considered in our simulations. In the first case, production taxes finance the additional public infrastructure investment and foreign financing (borrowing) provides resources in the second case. Our quantitative results reveal that public infrastructure investments have the same direction of impact whether funded by taxation or international financing (borrowing), particularly when looking at the macroeconomic gains and poverty reduction. However, in the very short run (the first period, i.e., year 1), tax financing puts a strain on output in the industrial sector (because this sector faces the largest burden of taxes, particularly of production taxes) and thus reduces economic growth in the first period. However, financing from international borrowing has a certain Dutch disease-like impact in the first period, as indicated by a decline in exports. Most of our results, particularly in the real sector of the economy, are in line with earlier work by Khan and Sasaki (2001).

Real GDP grew in the longer run by 1.01 and $1.29 \%$, respectively under tax and international financing. Household consumption in these scenarios increased by 0.94 and $1.2 \%$ over this time frame. In the tax financing scenario, long run increases in production make up for reduced consumption and investment in the first period. The poverty headcount ratio respectively improved by 0.31 and $0.4 \%$ under tax financing and international borrowing. Inequality is somewhat lower in the long run in both cases.

Like with any other quantitative approach, our results should be interpreted in consideration of model limitations. Furthermore the impact of public investment not only depends on the size of investment but the efficiency with which this invested sum is utilized and absorbed. It also depends on which sectors are targeted by the government interventions. It is important not to compete with the private sector and instead only focus on areas characterized by market failure. In raising revenues through taxation, it will be important to see which sectors are taxed and in which manner(s). Achieving an increase in direct taxes will most easily be realized 
if the government takes measures to remove barriers to entry and exit in the market and to remove state-designed procedures which distort consumption and production decisions.

Acknowledgements PEP is financed by the Department for International Development (DFID) of the United Kingdom (or UK Aid) and the Government of Canada through the International Development Research Center (IDRC). This particular program of research received separate funding from the Australian Agency for International Development (AusAID). We thank participants in several PEP general meetings, the 2013 GTAP annual conference in Beijing, the 2013 GDN annual conference in Manila and the 15th Sustainable Development Conference"Sustainable Development in South Asia: Shaping the Future"-in Islamabad (2012) for helpful comments. We also salute the support and advice provided by governmental and non-governmental counterparts. Acknowledgements are also due to John Cockburn, Luca Tiberti and Yazid Dissou for technical supervision, as well as an anonymous referee for the excellent comments and inputs. Mumtaz Masud Ahmad, Ghulam Samad and Ahmed Pirzada provided support with data and background statistics on infrastructure subsectors.

Open Access This chapter is distributed under the terms of the Creative Commons Attribution Noncommercial License, which permits any noncommercial use, distribution, and reproduction in any medium, provided the original author(s) and source are credited.

\section{References}

Adam C, Bevan D (2006) Aid and the supply side: public investment, export performance, and Dutch disease in low-income countries. World Bank Econ Rev 20(2):261-290

ADB (2008) Pakistan private sector assessment. Asian Development Bank, Manila

Ahmed V, O' Donoghue C (2010) External shocks in a small open economy. Lahore J Econ 15 (1):45-90

Apergis N, Payne JE (2009) Energy consumption and economic growth in Central America: Evidence from a panel cointegration and error correction model. Energy Econ 31(2):211-216

Aschauer DA (1989) Is public expenditure productive? J Monet Econ 23(2):177-200

Aschauer DA (1998) The role of public infrastructure capital in Mexican economic growth. Quarterly J Econ 96:605-629

Banister D, Thurstain-Goodwin M (2010) Quantification of the non-transport benefits resulting from rail investment. J Trans Geography 19(2):212-223

Barrios S, Bertinelli L, Strobl E (2010) Trends in rainfall and economic growth in Africa: a neglected cause of the African growth tragedy. Rev Econ Stat 92(2):350-366

Boccanfuso D, Joanis M, Richard P, Savard L (2012) A comparative analysis of funding schemes for public infrastructure spending in Quebec. GREDI working paper no 12-10, Université de Sherbrooke

Canning D, Pedroni P (2008) Infrastructure, long-run economic growth and causality tests for cointegrated panels. Manch Sch 76(5):504-527

Chohan B, Imran M, Cheyne C (2011) Roads for economic development: an analysis of urban transport policies of New Zealand and Pakistan. In: Australasian transport research forum 2011 proceedings, Adelaide, 28-30 Sept 2011

Cockburn J, Duclos J-Y, Tiberti L (2011) Notes on microsimulation model and results for Benin, mimeo, PEP document prepared for the PEP-AusAID project "simulate the distributive impacts of different growth strategies" 
Crafts N (2011) Transport infrastructure investment: implications for growth and productivity. Oxf Rev Econ Policy 25(3):327-343

Devarajan S, Swaroop V, Zhou H (1996) The composition of public expenditure and economic growth. J Monet Econ 37(3):313-344

Dissou, Y, Didic S (2011) Public infrastructure and economic growth. Working paper, Department of Economics, University of Ottawa

Dodonov B, Von Hirschhausen C, Opitz P, Sugolov P (2002) Efficiency infrastructure supply for economic development in transition countries: the case of Ukraine. Post-Communist Econ 14 (2):149-167

Estache A, Perrault J-F, Savard L (2009) Impact of infrastructure spending in mali: a CGE modeling approach. ECARES working papers: 2009_009, UniversitéLibre de Bruxelles, Ecares

Fan, S, Chan-Kang C (2005) Road development, economic growth and poverty reduction in China. Research report abstract 38, International Food Policy Research Institute, Washington, DC

Ghani E, Din M (2006) The impact on public investment on economic growth in Pakistan. Pak Dev Rev 45(1):87-98

Giesecke J, Dixon PB, Rimmer MT (2008) Regional macroeconomic outcomes under alternative arrangements for the financing of public infrastructure. Pap Reg Sci 87(1):3-31

Grey D, Sadoff CW (2007) Sink or swim? Water security for growth and development. Water Policy 9:545-571

Haque NU, Pirzada A, Ahmed V (2011) Rethinking connectivity as interactivity: a case study of Pakistan. Background paper for Planning Commission's new growth strategy

Holtz-Eakin D (1994) Public sector capital and the productivity puzzle. Rev Econ Stat 76:12-21

Hong J, Chu Z, Wang Q (2011) Transport infrastructure and regional economic growth: evidence from China. Transportation 38(5):737-752

Hye QMA, Riaz S (2008) Causality between energy consumption and economic growth: the case of Pakistan. Lahore J Econ 13(2):45-58

JBICI (2007) Impact assessment of irrigation infrastructure development on poverty alleviation: a case study from Pakistan. Research paper no 31, Japan Bank for International Cooperation Institute

Khan MT, Komei S (2001) Roles of public capital in Pakistan's economy: productivity, investment and growth analysis. Rural Urban Develop Stud 13:43-161

Lall SV (2006) Infrastructure and regional growth, growth dynamics and policy relevance for India. Ann Reg Sci 41:581-599

Lee C, Chang C (2008) Energy consumption and economic growth in Asian economies: A more comprehensive analysis using panel data. Resource Energy Econ 30:50-65

Levy S (2007) Public investment to reverse Dutch disease effect: the case of Tchad. J Afr Econ 16 (3):439-484

Lin JY (2011) New structural economics: a framework for rethinking development. World Bank Res Obs 26(2):193-221

Marazzo M, Scherre R, Fernandes E (2010) Air transport demand and economic growth in Brazil: a time series analysis. Trans Research Part E 46(2):261-269

Mehmood H, Wahab MA, Ahmed V (2013) Human resource development and foreign remittances: The case of South Asia, SDPI Working Paper Series (W-130). Sustainable Development Policy Institute

Montolio D, Solé-Ollé A (2009) Road investment and regional productivity growth: The effects of vehicle intensity and congestion. Papers in Region Sci 88(1):99-118

Nketiah-Amponsah E (2009) Public spending and economic growth: evidence from Ghana (1970-2004). Dev South Afr 26(3):477-497

Pasha HA (2011) Evaluation of public sector development programme. Planning Commission, Government of Pakistan, Islamabad

Planning Commission (2011) Framework for economic growth. Government of Pakistan, Islamabad 
Ramirez MD (2004) Is public infrastructure spending productive in the Mexican case? A vector error correction analysis. J Int Trade Econ Dev 13(2):159-178

Rehman JU, Iqbal A, Siddiqui MW (2010) Cointegration-causality analysis between public expenditures and economic growth in Pakistan. Eur J Soc Sci 13(4):5-22

Rioja FK (2001) Growth, welfare, and public infrastructure: A general equilibrium analysis of Latin American economies. J Econ Develop 26 (2):119-130

Sahoo P, Dash RK (2009) Economic growth in South Asia: role of infrastructure. Working paper no 288, Institute of Economic Growth

Samad G, Ahmed V (2011) Trade facilitation for economic corridors in South Asia: the perspective of Pakistan. Mimeo, Research Information Systems for Developing Countries, New Delhi

Sánchez-Robles B (1998) Infrastructure investment and growth: some empirical evidence. Contemp Econ Policy 16(1):98-109

SBP (2007) The Pakistan infrastructure report. Infrastructure Taskforce, State Bank of Pakistan, Karachi

Siddiqui R (2008) Quantifying the impacts of development of transport sector in Pakistan. In: Proceedings from 23rd annual general meeting of Pakistan Society of Development Economists, Islamabad

Straub S, Vellutini C, Warlters M (2008) Infrastructure and economic growth in East Asia. Policy research working paper 4589 , World Bank

UNIDO (2009) Public capital, infrastructure and industrial development. Working paper 15/2009, Research and Statistics Branch

USAID (2007) Energy sector assessment for Pakistan. United States Agency for International Development, Islamabad

Wolde-Rufael Y (2009) Energy consumption and economic growth: the African experience revisited. Energy Econ 31:217-224

World Bank (2007) Pakistan infrastructure implementation capacity assessment. South Asia Sustainable Development Unit, South Asia Region, World Bank

World Bank (2008) Pakistan's water economy: running dry. Policy notes, Issue 17. World Bank, Islamabad

World Bank (1994) World development report. World Bank, Washington, DC 